\title{
Physiology of fruit cracking in wax apple (Syzygium samarangense)
}

\section{Pei-Luen Lu' ${ }^{1}$ and Chin-Ho Lin $^{2}$}

${ }^{1}$ Department of Botany, University of Hawaii at Manoa, Honolulu, Hawaii 96822, USA; ${ }^{2}$ Department of Life Science, National Chung-Hsing University, Taichung 402, Taiwan.

\begin{abstract}
The cause of fruit cracking can be diverse and the reasons vary among species. Wax apple (Syzygium samarangense) fruit is an economically valuable fruit in Southeast Asia and in Taiwan. The main problem in the production of wax apple is cracking which reduces its market value. The aim of this study is to identify the factors associated with fruit cracking in wax apple. Results showed that the contents of total soluble sugars and total titratable acid were both $20 \%$ higher in cracked fruits than in uncracked fruits, and the osmotic potential was $40 \%$ lower; water potential was similar; turgor pressure was $60 \%$ higher, and specific activity of polygalacturonase was $131 \%$ higher. Based on the above results, the physiological factors for fruit cracking in wax apple are hypothesized. The increase in total soluble sugars and total titratable acid during fruit maturation leads to decreased tissue osmotic potential. Water absorption in response to this decrease in osmotic potential can cause cells to swell, which increase the turgor pressure resulting in rupture of the cells and tissues. The increase in polygalacturonase activity weakens the cell walls. Those combined factors result in fruit cracking.
\end{abstract}

Key words: soluble sugar, polygalacturonase activity, water relations.

\section{Introduction}

Wax apple (Syzygium samarangense (Blume) Merrill \& Perry, Fam. Myrtaceae), a perennial evergreen tree species, is a native to Malaysia, Papua New Guinea, Indonesia, and Thailand (Wu et al. 1994). This species have been widely grown in Indonesia, Thailand, Cambodia, Laos, Vietnam, Philippine, Taiwan and China (restricted to South), and also cultivated in India, Tanzania (mainly in Zanzibar and Pemba), Surinam and Jamaica (Morton 1987; Wu et al. 1994). Syzygium samarangense is commonly called wax apple, Java apple, water apple, wax jambu (Morton 1987). Wax apple fruit is one of the economically important fruits in Taiwan (Shü et al. 1996; Chen 2010). Wax apple fruits are bell-shaped, narrow at the base, very broad, flattened, indented and adorned with the four fleshy calyx lobes at the apex; $3.4-5 \mathrm{~cm}$ long, $4.5-5.4 \mathrm{~cm}$

*For correspondence, e-mail: peiluen@hawaii.edu, tel: 1-808-990-8186 wide (Morton 1987; Wu et al. 1994). The flesh is juicy and spongy, and the color of the fruit can be light-red, dark-red and green. The skin of wax apple fruit is very thin and cannot be easily separated from the flesh. The tree fruits all year round (Morton 1987; Wu et al. 1994).

Fruit cracking is common in many edible fruits, but its mechanism is not well understood in many species (Opara et al. 1997). Fruit cracking is a physical failure of the fruit skin that manifests as fractures in the cuticle or skin of certain fruits, or splitting, a more extreme form of cracking that penetrates deep into the flesh (Opara et al. 1997). Cracking of fruit has been observed in many species, including tomato (Solanum lycopersicum) (Frazier and Bowers 1947; Schilstra and Janse 1986; Shackel et al. 1991), cherry tomato (Solanum lycopersicum var. cerasiforme) (Lichter et al. 2002), apple (Malus domestica) (Goode et al. 1975), sweet cherry (Prunus avium) (Verner and Blodgett 1931; Manganarisa et al. 2007), French prunes (Prunus domestica L. cv. French) (Milad and 
Shackel 1992), jostaberry (Ribes nidigrolaria), gooseberry (Ribes uva-crispa), black currant (Ribes nigrum) (Khanal et al. 2011). In the wax apple, cracking occurs at the calyx end (stem-end scar) and on the side, and there may be single split or several splits, and cracking can develop in all seasons during fruit maturation (Wang and Hung 2005). Fruit cracking usually results in considerable financial loss to the farmers, but the physiological mechanism of fruit cracking in wax apples is still not understood (Wu et al. 2002).

Hydrolytic enzymes activities in plant cell wall that contribute to reduced skin elasticity have been investigated in French prune and papaya (Milad and Shackel 1992; Krongyut et al. 2011), but no reports were found on wax apple. Plant cell wall hydrolytic enzymes have been shown to change the structure of the cell wall in apple, tomato, papaya, and cherry (Huber 1983; Brady 1987; Andrews and Li 1995; Krongyut et al. 2011). One such enzyme, polygalacturonase (PG), cleaves the linkage of $\alpha$-(1-4)-galacturonan in the pectin chain (Fisher and Bennett 1991), and the increased activity of PG induces fruit softening (Eskin 1979) in tomato (Solanum lycopersicum) (Wallner and Walker 1975), papaya (Carica papaya) (Paull and Chen 1983; Krongyut et al. 2011), cucumber (Cucumis sativus) (Miller et al. 1987), cherry (Prunus avium) (Barrett and Gonzalez 1994; Andrews and Li 1995). Therefore, we examined whether PG plays a role in cracking of wax apple.

As most fruits mature, biochemical processes convert starch into sugar, resulting in changes in firmness and texture of the fruit (Speirs and Brady 1991; Domíngueza et al. 2011). A cultivar of cherry with high sugar content was more predisposed to fruit cracking; decreased osmotic potential and increased turgor pressure in fruits with high sugar were suspected as important factors causing fruit cracking (Christensen 1972). In addition, in some studies, treatment of tissues with $\mathrm{H}^{+}$has been reported to increase softening of the cell wall in $<10$ minutes (Clelend 1971) and promote fruit cracking (Bangerth 1973; Lichter et al. 2002). In this study, we investigated the water relations of fruit to determine the role of sugars and titratable acid in fruit cracking of wax apple.

\section{Materials and Methods}

\section{PLANT MATERIALS}

Mature and even-sized field-grown wax apple (Syzygium samarangense) fruits were randomly selected from five-year- old wax apple trees in three different orchards located in Pingtung (tropics), Kaoshung (tropics), and Nantou (subtropics) in Taiwan (rainfall and elevation are similar on the three locations). Cracked $(n=45)$ and uncracked $(n=45)$ fruits were randomly collected from 15 different trees on each orchards (each individual tree had both cracked and uncracked fruits; three cracked and three uncracked fruits on a randomly selected tree were collected). A cracked fruit was defined as one having a skin break $>2 \mathrm{~mm}$ long. Fruit and trees selected were disease-free with the same treatment during growth.

\section{SUGAR ANALYSIS}

The amount of glucose, fructose, sucrose, maltose and lactose were quantified by high-performance liquid chromatography (HPLC) using the procedure of AVRDC (1989). Fruits were squeezed with a juicer and the juice was collected and centrifuged at $20,000 \mathrm{xg}$ at $4^{\circ} \mathrm{C}$ for $20 \mathrm{~min}$ to obtain the supernatant. The supernatant was filtered through a PVDF (polyvinylidiene fluoride) $0.45 \mu \mathrm{M}$ millipore. The filtrate was analyzed and quantified by HPLC system (HITACHI L-7200 Autosample injector, HITACHI L-6200 Intelligent Pump) using a guard column (Licherosorb RP-18 column, LiChroCART 125-4 HPLC-Cartidge, LiChrosher 100RP-18 endcapped $5 \mu \mathrm{m}, \mathrm{MERCK}$ ), and elution with $82 \%$ (v/v) Acetonitrile (MERCK) solution at a constant flow of 1.0 $\mathrm{mL} \min ^{-1}$. The individual fractions were detected with a refractive index detector (model HITACHI L-7420 UV-VIS, Japan) and analyzed with integration software (Valuchrom, Bio-Rad) and detection at $229 \mathrm{~nm}$ by a Chromato-Integrator (model HITACHI D2500). Standards of D(-)-Fructose (Fluka 47740), D(+)-Glucose anhydrous (Fluka 49140), D-Sucrose (Fluka 84100), D(+)-Maltose monohydrate (Fluka 63419), $\mathrm{D}(+)$-Lactose monohydrate (Fluka 6134) were processed in the same way as the samples.

\section{MEASUREMENT OF TOTAL TITRATABLE ACID}

The $\mathrm{pH}$ of centrifuged juice was measured using a standard digital pH meter (Mettler-Toledo Ltd., LE4 1AW, UK), and the titratable acidity was measured by titrating the juice sample with $0.02 \mathrm{~N} \mathrm{NaOH}$ until the $\mathrm{pH}$ reached to 8.3, using a buretmeter (Burette Digital III Brand, Wertheim, Germany) (Chu et al. 1990). The experiment was done at room temperature $\left(25^{\circ} \mathrm{C}\right)$. 
Table 1. Comparison of sugar contents ( $\mathrm{mg} \mathrm{g}^{-1}$ fresh weight) and water relations parameters of uncracked and cracked fruits of wax apple. Each value is the mean of 15 fruits per orchard. Values in a column followed by different alphabets are significantly different $(p<0.05$, paired $t$-test).

\begin{tabular}{|c|c|c|c|c|}
\hline & Uncracked & Cracked & Degree of freedom & $t$-value \\
\hline Total sugar & $7.64 \pm 0.1 \mathrm{a}$ & $9.14 \pm 0.1 b$ & 44 & -13.65 \\
\hline Glucose & $3.17 \pm 0.1 \mathrm{a}$ & $3.90 \pm 0.1 b$ & 44 & -26.51 \\
\hline Fructose & $2.84 \pm 0.1 \mathrm{a}$ & $3.53 \pm 0.1 b$ & 44 & -36.69 \\
\hline Sucrose & $1.63 \pm 0.1 \mathrm{a}$ & $1.71 \pm 0.1 \mathrm{a}$ & 44 & -2.07 \\
\hline Water potential $(\Psi, \mathrm{MPa})$ & $-0.36 \pm 0.00 \mathrm{a}$ & $-0.37 \pm 0.00 \mathrm{a}$ & 44 & -2.86 \\
\hline Osmotic potential ( $\Psi$ s, MPa) & $-1.08 \pm 0.15 \mathrm{a}$ & $-1.52 \pm 0.11 b$ & 44 & -7.87 \\
\hline Turgor pressure ( $\Psi \mathrm{p}, \mathrm{MPa})$ & $+0.72 \pm 0.15 \mathrm{a}$ & $+1.16 \pm 0.11 b$ & 44 & -3.76 \\
\hline
\end{tabular}

\section{MEASUREMENT OF WATER RELATIONS PARAMETERS}

Fruit discs ( $8 \mathrm{~mm}$ diameter, $1 \mathrm{~mm}$ thick) were excised from cylinders of pericarp, and then incubated in sample chambers (model C-52, Wescor, Utah, USA) at $25^{\circ} \mathrm{C}$ for $2 \mathrm{~h}$. Three discs were used from each fruit. The water potential of fruit discs was measured with a thermocouple psychrometer (HR33T Dewpoint Microvoltmeter, Wescor, Utah, USA) calibrated with standard $\mathrm{NaCl}$ solution $(1 \mathrm{M})$. The osmotic potential of fruit juice extracted from samples thawed in a bath at $25^{\circ} \mathrm{C}$ was measured using a vapour pressure osmometer (5500 Vapour Pressure Osmometer, Wescor, Utah, USA) calibrated with standard $\mathrm{NaCl}$ solution. Turgor pressure $\left(\psi_{\mathrm{p}}\right)$ was calculated by subtracting osmotic potential $\left(\psi_{\mathrm{s}}\right)$ from water potential $(\psi)$ (Nobel 1983).

\section{POLYGALACTURONASE (PG) ASSAY}

Juice was collected and centrifuged at $20,000 \mathrm{xg}$ at $4^{\circ} \mathrm{C}$ for 20 min to obtain the supernatant containing polygalacturonase (PG). PG activity was assayed spectrophotometrically following derivation of the reaction product with UVabsorbing 2-cyanoacetamide. The reaction mixture consisted of $100 \mathrm{iL}$ enzyme extract and $500 \mathrm{iL} 0.25 \%(\mathrm{w} / \mathrm{v}) \mathrm{na}-$ polygalacturonic acid (Sigma Chemical Co.) in $40 \mathrm{mM}$ sodiumacetate buffer ( $\mathrm{pH} 4.4$ ), was incubated at $30^{\circ} \mathrm{C}$ for $2 \mathrm{~h}$. The reaction was terminated with $2 \mathrm{ml}$ cold borate buffer (100 $\mathrm{mM}, \mathrm{pH} 9.0$ ), followed by addition of $200 \mathrm{iL}$ of $1 \% 2-$ cyanoacetamide (Aldrich Chemical Co). The reaction vessel was immersed in boiling water for $10 \mathrm{~min}$, and then cooled at $25^{\circ} \mathrm{C}$ for $20 \mathrm{~min}$. Absorbance at $276 \mathrm{~nm}$ was measured with a spectrophotometer (Model U-2001, Hitachi, Tokyo, Japan). $\alpha$-D-galacturonic acid (Sigma, Saint Louis, MO, USA) was used as a standard (Gross 1982).
Total protein content was determined in the crude extracts by Bradford's method using Bio-Rad reagents (Bradford 1976). Enzyme activities were expressed on a basis of total protein type.

\section{STATISTICAL ANALYSIS}

The experimental design was a completely randomized with fifteen replications per orchard. All statistical values are reported as the means \pm SD (Ott and Longnecker 2001). All analyses were performed in triplicate. The coefficients of variation were in all instances less than $10 \%$, thus the values for each study parameter for each fruit type was averaged to obtain a mean value per tree. Comparison between mean values of water relations parameters and sugar content of cracked and uncraked fruits were done by paired $t$-test using MiniTab 15.

\section{Results}

Both cracked and uncracked fruits had glucose, fructose, and sucrose, but no maltose and lactose. The concentrations of simple sugars such as glucose and fructose were significantly higher in cracked fruit (respectively 23\% and 24\% higher) than in uncracked fruits (Table 1). The total soluble sugars in cracked and uncracked fruits were 9.14 and $7.64 \mathrm{mg} \mathrm{g}^{-1}$ fresh weight, respectively. The total soluble sugars were $20 \%$ higher in cracked fruit than in uncracked fruit (Table 1). The total titratable acid in cracked fruit $\left(34.0 \pm 0.07 \mu \mathrm{mol} \mathrm{ml^{-1 }}\right)$ was significantly higher $(p<0.05)$ than in uncracked fruit $(28.0 \pm$ $0.03 \mu \mathrm{mol} \mathrm{ml}^{-1}$ ) (Figure 1). Water potential of cracked fruit did not differ significantly with that of uncracked. There was 


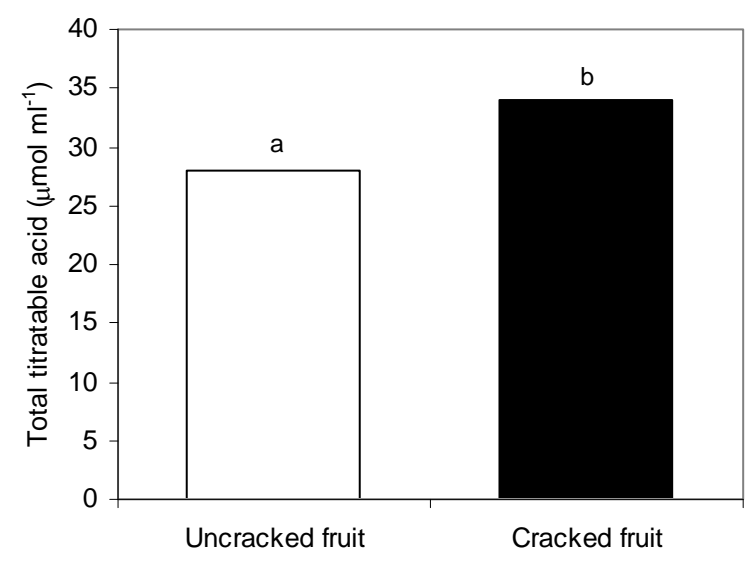

Figure 1. The comparison of total titratable acid of normal fruit and cracked fruit in wax apples. Values are reported as the means $\pm \operatorname{SD}(n=45)$. Bars with different letters are significantly different by paired $t$-test $(t=-7.64, p=0.01)$.

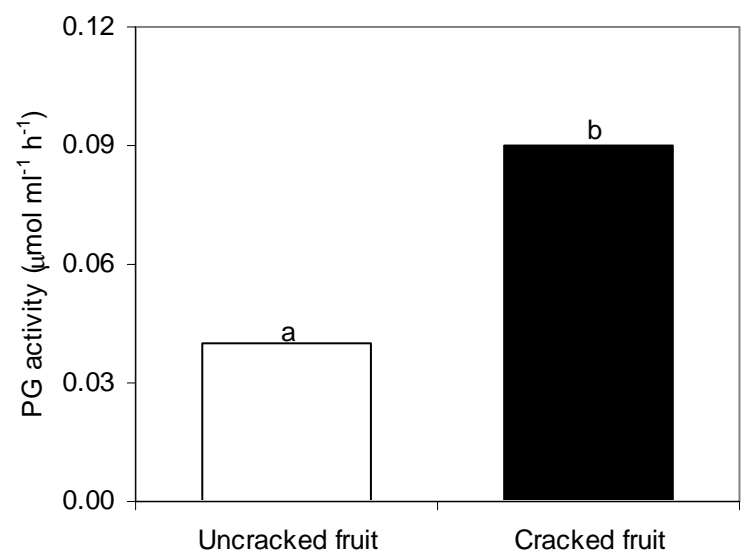

Figure 2. The comparison of polygalacturonase specific activity of normal fruit and cracked fruit in wax apples. Values are reported as the means $\pm \operatorname{SD}(n=45)$. Bars with different letters are significantly different by paired $t$-test $(t=-10.91, p<0.001)$.

significant difference in osmotic potential of the cracked and uncracked fruits (Table 1). Osmotic potential was $20 \%$ higher in cracked than in uncracked fruit. The high osmotic potential caused the fruit to absorb more water, resulting in a higher turgor pressure in cracked fruits (Table 2).

The specific activity of PG (as galacturonic acid per mg protein) in cracked fruit was $0.09 \pm 0.02 \mu \mathrm{mol} \mathrm{ml}^{-1} \mathrm{~h}^{-1}$ while in uncracked fruit it was $0.04 \pm 0.0 \mu \mathrm{mol} \mathrm{ml}^{-1} \mathrm{~h}^{-1}$ (Figure 2). Polygalacturonase activity was $131 \%$ higher in cracked than in uncracked fruit.

\section{Discussion}

Our study provides three important observations about fruit cracking in wax apple. First, total soluble sugar and total titratable acid were positively related to fruit cracking. Second, fruit cracking was accompanied by increased PG enzyme activity. Third, lower osmotic potential drove fruit cracking. The study of fruit cracking in wax apple will benefit from an assay inducing cracking and facilitate evaluation of the effect of different treatments.

The skin of wax apple is different from the other fruits studied previously such as tomato and cherry because the skin of wax apple cannot be separated (i.e. exocarp is directly connected into the mesocarp) and its exocarp is thin compared to other fruits (Morton 1987). Therefore, when cracking occurs, not only the exocarp but also the mesocarp is broken. This type of fruit is easily broken by external force or unclear internal factors (Morton 1987). This study provides the potential explanations to decipher the internal factors that were unclear in previous research. One possible factor is the low osmotic potential due to the higher concentration of total soluble sugar and total titratable acid. This triggers high turgor pressure to break the skin. Cracking only in some fruits indicate the genetic polymorphism reflected in the fruits (Bach and Kelly 2007).

According to the epidermis-growth-control theory which describes that the epidermis is responsible for the restriction of organ growth (Kutschera and Niklas 2007), originally, the cell should start cell growth and strengthen cell wall in response to the extrusion. However, the development of fruit in the mature stage will cease or become slower (Stolle-Smits et al. 1999). Due to higher pressure inside the cell than the outside, a fruit can maintain a pressure balance externally and internally if the fruit has firm skin. The synthesis of new plant cell wall would also weaken the cell wall, and during the generation of new cells, the acidity and PG enzyme activity usually increase (Wallner and Walker 1975; Schilstra and Janse 1986). Overall, the causes of fruit cracking in wax apple from our data support these previous studies.

Cracking may result from normal processes that occur too rapidly for cells to adjust to the changes even though plant's cuticle is flexible to protect the environmental change (Domíngueza et al. 2011). Solute gradients in cells and tissues caused by transport of solutes or conversion of starch to sugars or other soluble solids leads to water movement by osmosis as equilibration occurs (Nobel 1983). During the 
equilibration process, water gets absorbed through the cell membrane producing turgor pressure against cell walls, causing cells to swell; such swelling is essential for growth and tissue rigidity (Nobel 1983). This study hypothesizes that water enters into the fruit in response to a decreased tissue osmotic potential and then exerts pressure on the cell membranes. Our results accepts this hypothesis and also supports the experiments examined in other species in response for fruit cracking in sweet cherry (Anderson and Richardson 1982; Seske 1987; Seske 1995) and grape (Considine and Kriedmann 1972).

Wax apple's fruit is made by primary cell covering by plant cuticle and includes higher proportion of pectin with some spongy structure at the center or base of fruit (Morton 1987). On the inner side of the plant cuticle, cutin is mixed with polysaccharides, which is physically or chemically interconnected with epidermis cell wall (Domíngueza et al. 2011). Knowledge of these interconnections is not yet clear but would be important to protect plants by increasing its elasticity (Domíngueza et al. 2011). Cutin is one kind of waxy polymers that are the main components of the plant cuticle (Holloway 1982). Polygalacturonase degrades polysaccharides present in the cell walls of plants by hydrolysis of the glycosidic bonds and the major component of pectin (Jones et al. 1972). In this study, PG enzyme activity was $131 \%$ higher in cracked fruits than in uncracked fruits, which suggests PG enzyme may be the major enzyme to soften the skin of fruit in mature wax apple. The breaking of polysaccharides by PG enzyme loosens the structure of the mixed cutin with polysaccharides, and increases the solutes in plant epidermis and exocarp resulting in more water absorption and weakening the protection of plant cuticle. Once the orchards faces heavy rain, plants uptake more water than the usual time, and thus fruit cracking occurs due to the high turgor pressure shortly after the heavy rainfall. The present data also suggests that PG enzyme activity increased in response to the pressure developed during fruit maturation. Further studies are required to provide more evidence to demonstrate that the synthesis of PG enzyme can be induced by an abrupt increase in turgor pressure, which could reduce skin elasticity and lead to fruit cracking.

The total titratable acid in cracked fruit is higher than in uncracked fruit (Figure 1). Therefore, the acidity in the plant cell is related to the series of reactions, which also induces PG enzyme activity and leads to cell wall softening. The data has supported the previous studies which showed the relation between the acid factor and increasing fruit cracking (Bangerth
1973; Köhler and Spatz 2002; Lichter et al. 2002). Total soluble sugar mainly affects on osmotic potential and the total titratable acid affects on cell wall softening. The sugar and acidity may both play a role in PG enzyme signal transduction (Price et al. 2004). However, the interaction between total soluble sugar and acid is still not clear in wax apple.

This study explored the physiological reasons for fruit cracking of wax apple. Further research can be designed on manipulative experiments to avoiding fruit cracking in wax apple. The data presented here can be helpful to validate the recently developed fruit cracking prediction model under a real environment conditions (Ehret et al. 2008). Based on our data, the cause of wax apple fruit cracking is similar to what the previous researchers found in tomato (Huang and Snapp 2004). It has been suggested that calcium with wax be sprayed to fruits of tomatoes during their maturity period, or at least before the heavy rain for preventing fruit cracking (Huang and Snapp 2004). This suggestion could probably be followed to prevent fruit cracking of wax apple too. Because acid and chelating solutions reduce cracking, it was suggested to make neutral calcium spray by adjusting $\mathrm{pH}$ value before applying to fruits (Lichter et al. 2002). However, the best time and the concentration of spray solution for wax apple require further study.

\section{Acknowledgements}

We are grateful to Meng-Jiau Tseng who advised us for the research. Thanks are also due to Yi-Wei Wen and Asheshwor Man Shrestha for their suggestions. We would also like thank lab-mates and Yu-Mei Hsiu who helped us in the field work, and the farmers who were very kind and facilitated us to conduct research in their orchards. This work was funded by the National Science Council (NSC 92-2815-C-005 -029-B.) of Taiwan granted to Pei-Luen Lu.

\section{References}

Anderson P.C. and Richardson D.G. 1982. A rapid method to estimate fruit water status with special reference to rain cracking of sweet cherries. Journal of American Society for Horticultural Science 107: 441-444.

Andrews P.K. and Li S. 1995. Cell wall hydrolytic enzyme activity during development of nonclimacteric sweet cherry (Prunus avium L.) fruit. Journal of Horticultural Science and Biotechnology 70: 561-567. 
AVRDC. 1989. Report. Asian Vegetable Research and Development Center, Shanhua, Tainan, Taiwan, Republic of China.

Bach C. and Kelly D. 2007. Mistletoe fruit-colour polymorphism and differential success in a habitat mosaic. Austral Ecology 17: 509-514.

Bangerth F. 1973. Investigations upon calcium related physiological disorders. Journal of Phytopathology 77: 2037.

Barrett D.M. and Gonzalez C. 1994. Activity of softening enzymes during cherry maturation. Journal of Food Science 59: 574-577.

Bradford M.M. 1976. A rapid and sensitive method for the quantitation of microgram quanties of protein utilizing the principle of protein-dye binding. Analytical Biochemistry 72: 248-254.

Brady C.J. 1987. Fruit ripening. Annual Review of Plant Physiology 38: 155-178.

Chen W.H. 2010. Agricultural Statistics Yearbook. Council of Agriculture, Executive Yuan, Taipei, Taiwan, Republic of China.

Christensen J.V. 1972. Cracking in cherries. IV. Physiological studies of the mechanism of cracking. Acta Agriculturce Scandinavica Section 22: 153-162.

Chu C., Dai Z.M., Ku S.B. and Ewards G.E. 1990. Induction of crassulacean acid metabolism in the facultative halophyte by abscisic acid. Plant Physiology 93: 1253-1260.

Clelend R. 1971. The plant cell wall synthesis and metabolism. Annual Review of Plant Physiology 22: 197-222.

Considine J.A. and Kriedmann P.E. 1972. Fruit splitting in grapes. Determination of the critical turgor pressure. Australian Journal of Agricultural Research 23: 17-24.

Domíngueza E., Cuarteroa J. and Herediab A. 2011. An overview on plant cuticle biomechanics. Plant Science 181: 77-84.

Ehret D.L., Hill B.D., Raworth D.A. and Estergaard B. 2008. Artificial neural network modelling to predict cuticle cracking in greenhouse peppers and tomatoes. Computers and Electronics in Agriculture 61: 108-116.

Eskin N.A.M. 1979. The plant cell wall. In: Plant Pigments, Flavors and Textures: Textural Components of Food (N.A.M. Eskin, ed.), pp. 123-138. Academic Press, New York, USA.

Fisher R.L. and Bennett A.B. 1991. Role of cell wall hydrolases in fruit ripening. Annual Review of Plant Physiology and Plant Molecular Biology 42: 675-703.

Frazier W.A. and Bowers J.L. 1947. A final report on studies of tomato fruit cracking in Maryland. Proceedings of American Society for Horticultural Science 49: 241-255.

Goode J.E., Fuller M.M. and Hyrycz K.J. 1975. Skin-cracking of Cox's Orange Pippin apples in relation to water stress. HortScience 50: 265-269.

Gross K.C. 1982. A rapid and sensitive spectrophotometric method for assaying polygalactironase using 2cyanoacetamide. HortScience 17: 933-934.

Holloway P.J. 1982. The chemical constitution of plant cutins. In: The Plant Cuticle (D.F. Cutler, K.L. Alvin and C.E. Price, eds.), pp 45-85. Academic Press London, UK.

Huang J and Snapp S.S. 2004. A bioassay investigation of calcium nutrition and tomato shoulder check cracking defect.
Communication in Soil Science and Plant Analysis 35: 2771-2787.

Huber D.J. 1983. The role of cell wall hydrolases in fruit softening. Horticulture Reviews 5: 169-219.

Jones T.M., Anderson A.J. and Albersheim P. 1972. Hostpathogen interactions IV, studies on the polysaccharidedegrading enzymes secreted by Fusarium oxysporum f. sp. lycopersici. Physiological Plant Pathology 2: 153-166.

Khanal B.P., Grimm E. and Knoche M. 2011. Fruit growth, cuticle deposition, water uptake, and fruit cracking in jostaberry, gooseberry, and black currant. Scientia Horticulturae 128: 289-296.

Köhler L. and Spatz H.C. 2002. Micromechanics of plant tissues beyond the linear elastic range. Planta 215: 33-40.

Krongyut W., Srilaong V., Uthairatanakij A., Wongs-Aree C., Esguerra E.B. and Kanlayanarat S. 2011. Physiological changes and cell wall degradation in papaya fruits cv. 'Kaek Dum' and 'Red Maradol' treated with 1- methylcyclopropene. International Food Research Journal 18: 1251-1259.

Kutschera U. and Niklas K.J. 2007. The epidermal-growthcontrol theory of stem elongation: an old and new perspective. Journal of Plant Physiology 164: 1395-1409.

Lichter A., Dvir O., Fallik E., Cohen S., Golan R., Shemer Z. and Sagi M. 2002. Cracking of cherry tomatoes in solution. Postharvest Biology and Technology 26: 305-312.

Manganarisa G.A., Iliasb I.F., Vasilakakisa M. and Mignanic I. 2007. The effect of hydrocooling on ripening related quality attributes and cell wall physicochemical properties of sweet cherry fruit (Prunus avium L.). International Journal of Refrigeration 30: 1386-1392.

Milad R.E. and Shackel K.A. 1992. Water relation of fruit end cracking in French prune (Prunus domestica L. cv. French). Journal of American Society for Horticultural Science 117: 824-828.

Miller A.R., Damasso J.P. and Kretchman D.W. 1987. Mechanical stress, storage time, and temperature influence cell walldegrading enzymes, firmness, and ethylene production by cucumbers. Journal of American Society for Horticultural Science 112: 666-671.

Morton J.F. 1987. Fruits of Warm Climates. Florida Flair Books, Boynton Beach, FL, USA.

Nobel P.S. 1983. Biophysical Plant Physiology and Ecology. W.H. Freeman and Co., San Francisco, USA.

Opara L.U., Studman C.J. and Banks N.H. 1997. Fruit skin and cracking. Horticultural reviews 19: 217-262.

Ott R.L. and Longnecker M.T. 2001. An Introduction to Statistical Methods and Data Analysis. Fifth edition. Duxbury Press, Pacific Grove CA, USA.

Paull R.E. and Chen R.H. 1983. Postharvest variation in cell wall degrading enzymes of papaya during fruit ripening. Plant Physiology 72: 382-385.

Price J., Laxmi A., St Martin S.K. and Jang J.C. 2004. Global transcription profiling reveals multiple sugar signal transduction mechanisms in Arabidopsis. Plant Cell 16:21282150 .

Schilstra I. and Janse J. 1986. Swelling cracks in tomatoes: a problem not to be under-estimated. Groenten en Fruit 41: 39-41. 
Seske L. 1987. Fruit cracking in Norwegian growth sweet cherries. Acta Agriculturae Scandinavica Section 37: 325-328.

Seske L. 1995. Fruit cracking in sweet cherries (Prunus avium). Some physiological aspects - a mini review. Scientia Horticulture 63: 135-140.

Shackel K.A., Greve C., Labavitch J.M. and Ahmadi H. 1991. Cell turgor change associated with ripening in tomato pericarp tissue. Plant Physiology 97: 814-816.

Shü, Z.H., Wang D.N. and Sheen T.F. 1996. Wax apple as a potential economic crop for the world. In: Proceedings of International Conference on Tropical Fruits, Vol. I. (S. Vijaysegaran, M. Pauziah, M.S. Mohamed, S. Ahmad Tarmizi, eds.), pp. 69-73. Malaysian Agricultural Research and Development Institute (MARDI), Serdang, Selangor, Malaysia.

Speirs J. and Brady C.J. 1991. Modification of gene expression in ripening fruit. Australian Journal of Agricultural Research 18: $519-32$.

Stolle-Smits T., Beekhuizen J.G., Kok M.T.C., Pijnenburg M., Recourt K., Derksen J. and Voragen A.G.J. 1999. Changes in cell wall polysaccharides of green bean pods during development. Plant Physiology 121: 363-372.

Verner L. and Blodgett E.C. 1931. Physiological studies of cracking of sweet cherries. University of Idaho Agricultural Experiment Station Bulletin 184: 1-15.

Wallner S.J. and Walker J.E. 1975. Glycosidase in cell wall degrading extracts of ripening tomatoes. Plant Physiology 55: 94-98.

Wang D.N. and Hung J.J. 2005. Wax apple. In: Taiwan Agriculture Encyclopedia, Crop Edition 2 (J.H. Hung, T.D. Fan and L.N. Lin, eds.), pp. 109-120. Council of Agriculture, Taipei, Taiwan, Republic of China.

Wu J.S. 2002. Effects of Bagging and Screen House Culture on Fruit Quality of Wax Apple (Syzygium samarangense Merr. et Perry). Master Thesis. Institute of Tropical Agriculture and International Cooperation, National Pingtung University of Science and Technology, Taiwan, Republic of China.

Wu Z.-Y. and Peter H.R. 1994. Flora of China. Vol. 13. Beijing Science Press and Missouri Botanical Garden, St. Louis, USA. 